\title{
Increased amino acid clearance and urea synthesis in a patient with glucagonoma
}

\author{
T P Almdal, H Heindorff, L Bardram, H Vilstrup
}

\begin{abstract}
Fasting concentrations, clearance of exogenous infused amino acids, and lean body mass were studied in a patient with glucagonoma syndrome (fasting glucagon= $380 \mathrm{pmol} / \mathrm{l}$, normal range $15-45 \mathrm{pmol})$. The fasting concentrations of all amino acids were reduced. The clearances of alanine, arginine, glycine, isoleucine, leucine, lysine, methionine, proline, serine, threonine, and tyrosine were increased. The urea synthesis rate during amino acid infusion was $27 \mu \mathrm{mol} / \mathrm{kg}$ per minute (normal range 20-24 $\mu \mathrm{mol} / \mathrm{kg}$ per minute). The lean body mass of the patients was reduced to $59 \%$ of the expected value. It is suggested that the weight loss of patients with glucagonoma syndrome is partly due to increased hepatic conversion of amino acid nitrogen to urea nitrogen, resulting in decreased blood amino acid concentration, and secondary to this, organ protein catabolism, as shown by the decreased lean body mass.
\end{abstract}

The glucagonoma syndrome is associated with loss of body weight and decreased concentrations of blood amino acids. ${ }^{1}$ In normal man, hyperglucagonaemia reduces the amino acid concentration, ${ }^{23}$ but despite this urea synthesis is increased..$^{23}$ In rats, glucagon increases the hepatic uptake of amino acids ${ }^{4}$ and the rate of urea synthesis resulting in loss of organ nitrogen. ${ }^{5}$ This suggests that the decreased blood amino acid concentrations may be caused by increased hepatic clearance and conversion of amino acids to urea. Moreover, it suggests that the loss of body weight seen in the glucagonoma syndrome represents loss of body protein, and that this is secondary to the increased hepatic conversion of amino acids to urea. In man, the total protein content can be assessed by determination of the lean body mass. ${ }^{6}$

We have studied clearance of amino acids, rate of urea synthesis, and lean body mass in a patient with a glucagonoma.

\section{Case report}

The patient is a 52 year old woman (weight $52 \mathrm{~kg}$, height $172 \mathrm{~cm}$ ) suffering from non-specific skin lesions (pruritus and vesicles on the hands).

One year before the present investigation, increased urinary excretion of 5 hydroxyindole- acetic acid was found. Ultrasound showed multiple focal liver lesions in both lobes, but no primary tumor, and especially no lesions of the pancreas, were found. Liver biopsy specimen histology suggested a neuroendocrine tumor, and immunohistochemistry showed glucagonoma.

The plasma concentrations of glucagon were considerably raised (1500-1600 pmol/1; normal range $15-45 \mathrm{pmol} / \mathrm{l}$ ) and high concentrations of pancreatic polypeptide were also found. The concentrations of gastrin vasoactive intestinal polypeptide, somatostatin, secretin, and calcitonin were within the normal range.

Since diagnosis the patient has been treated with repeated courses of streptozotocin. Since then there has been a decrease in the plasma glucagon concentrations (to $380 \mathrm{pmol} / \mathrm{l}$ at the time of investigation).

\section{Methods}

The investigative procedure has already been described in detail. ${ }^{7}$ After an overnight fast blood samples were drawn for determination of fasting concentrations of plasma amino acids, total blood $\alpha$ amino-nitrogen, blood urea, blood glucose, plasma pancreatic glucagon, and insulin. An amino acid mixture (Intrafusin 10\%, Pfrimmer and Co, W Germany) was given as a two step intravenous infusion, firstly at a constant rate of $41 \cdot 2 \mu \mathrm{mol}$ of $\alpha$ amino-nitrogen $/ \mathrm{kg}$ body weight per minute for 60 minutes, followed by a constant infusion for 180 minutes at a rate of $22.3 \mu \mathrm{mol}$ of $\alpha$ amino nitrogen $/ \mathrm{kg}$ per minute. This resulted in constant amino acid concentrations for the last 120 minutes. During these 120 minutes the blood clearance of amino acids was calculated as the ratio between the infusion rate and the steady state concentration of the individual amino acids. Urine was collected quantitatively. The urea nitrogen synthesis rate (UNSR) during amino acid infusion was calculated as:

$$
\mathrm{UNSR}=(\mathrm{E} \times \mathrm{A}) /(1-\mathrm{L})
$$

where $E$ is the urinary excretion of urea-N, $A$ is the accumulation of urea- $\mathrm{N}$ in total body water, and $\mathrm{L}$ is the fractional gut hydrolysis taken to be $17 \% .^{89}$

The lean body mass (LBM) was calculated from three 24 hour urinary creatinine excretions $^{6}$ :

$\mathrm{LBM}=24$ hour creatinine $\times 3 \cdot 29+7 \cdot 28$ 
TABLE I Fasting amino acid concentrations ( $\mu \mathrm{mol} / \mathrm{l}$ ) in a patient with glucagonoma

\begin{tabular}{ll}
\hline $\begin{array}{l}\text { Amino acid } \\
\text { (95\% CI of normal mean value) }\end{array}$ & $\begin{array}{l}\text { Patient values } \\
\text { (\% of normal mean value })\end{array}$ \\
\hline Alanine (231-255) & $34(9)$ \\
Arginine (62-134) & $10(10)$ \\
Glutamine (481-553) & $63(12)$ \\
Glutamate (43-58) & $22(44)$ \\
Glycine (263-317) & $47(16)$ \\
Histidine (71-87) & $42(53)$ \\
Isoleucine (35-59) & $18(38)$ \\
Leucine (74-162) & $34(29)$ \\
Lysine (146-166) & $71(46)$ \\
Methionine (13-23) & $2(11)$ \\
Phenylalanine (50-84) & $31(46)$ \\
Proline (198-262) & $35(15)$ \\
Serine (107-167) & $27(20)$ \\
Threonine (112-160) & $18(8)$ \\
Tyrosine (53-67) & $17(28)$ \\
Valine (170-276) & $57(26)$ \\
\hline
\end{tabular}

$\mathrm{CI}=$ confidence interval

The results were expressed as a percentage of the expected value:

Expected $\mathrm{LBM}=0.74 \times$ expected body weight

The equation was derived from studies of body composition, ${ }^{10}$ and the expected body weight was calculated from the equation:"

Expected body weight $=0.62 \times$ height $(\mathrm{cm})-41$

The individual amino acid concentrations were determined by ion chromatography followed by postcolumn derivatisation with orthopthaldehyde and fluorescent detection, total blood $\alpha$ aminonitrogen values were determined by the dinitrofluorobenzene method, ${ }^{12}$ urea in blood and urine by the urease-Berthelot method, ${ }^{13}$ blood glucose by enzymatic analysis, ${ }^{14}$ and plasma insulin and pancreatic glucagon by radioimmunoassay techniques. ${ }^{15} 16$

The individual results for the patient are given together with the normal range, stated as the $95 \%$ confidence limits of normal individuals derived from, ${ }^{7}$ in parenethesis.

\section{Results}

Fasting blood glucose was $8.3 \mathrm{mmol} / 1$ (normal range $4 \cdot 0-5 \cdot 0 \mathrm{mmol} / \mathrm{l}$ ), fasting glucagon was 380 $\mathrm{pmol} / \mathrm{l}$ (normal range $15-45 \mathrm{pmol} / \mathrm{l}$ ), and fasting insulin was $11 \mathrm{mU} / 1$ (normal range 5-7 mU/l). Fasting blood concentrations of all amino acids were reduced (Table I). Amino acid infusion raised the concentration of total $\alpha$ aminonitrogen to an average of $2 \cdot 2 \mathrm{mmol} / \mathrm{l}$ (normal range $4 \cdot 7-5.5 \mathrm{mmol} / \mathrm{l})$. The urea nitrogen

\begin{tabular}{ll}
$\begin{array}{l}\text { TABLE II Clearance }(\mathrm{ml} / \mathrm{sec}) \text { of amino acids in a patient with } \\
\text { glucagonoma }\end{array}$ \\
\hline $\begin{array}{l}\text { Amino acid } \\
\text { (95\% CI of normal mean) }\end{array}$ & $\begin{array}{l}\text { Patient values } \\
(\% \text { of normal mean })\end{array}$ \\
\hline Alanine $(8 \cdot 1-9 \cdot 9)$ & $25 \cdot 1(260)$ \\
Arginine $(5 \cdot 8-12 \cdot 2)$ & $17 \cdot 0(190)$ \\
Glutamine + & $19 \cdot 1(142)$ \\
Glutamate $(5 \cdot 8-21 \cdot 0)$ & $15 \cdot 2(180)$ \\
Glycine $(6 \cdot 6-10 \cdot 0)$ & $4 \cdot 6(107)$ \\
Histidine $(3 \cdot 7-4 \cdot 6)$ & $9 \cdot 9(132)$ \\
Isoleucine $(6 \cdot 9-8 \cdot 1)$ & $9 \cdot 9(150)$ \\
Leucine $(6 \cdot 9-8 \cdot 2)$ & $10 \cdot 3(160)$ \\
Lysine $(5 \cdot 2-7 \cdot 2)$ & $24 \cdot 4(205)$ \\
Methionine $(9 \cdot 9-13 \cdot 9)$ & $7 \cdot 1(91)$ \\
Phenylalanine $(6 \cdot 0-9 \cdot 6)$ & $14 \cdot 5(230)$ \\
Proline $(3 \cdot 7-8 \cdot 8)$ & $20 \cdot 2(230)$ \\
Serine $(6 \cdot 7-10 \cdot 7)$ & $13 \cdot 8(290)$ \\
Threonine $(3 \cdot 7-5 \cdot 9)$ & $12 \cdot 4(282)$ \\
Tyrosine $(2 \cdot 5-6 \cdot 2)$ & $3 \cdot 3(103)$ \\
Valine $(2 \cdot 7-3 \cdot 7)$ & \\
\hline
\end{tabular}

$\mathrm{CI}=$ confidence interval synthesis rate during amino acid infusion was increased to $27 \mu \mathrm{mol} / \mathrm{kg}$ per minute (normal range $20-24 \mu \mathrm{mol} / \mathrm{kg}$ per minute).

The clearances of all amino acids were increased apart from those of glutamine+ glutamate, histidine, phenylalanine, and valine (Table II).

The body weight $(52 \mathrm{~kg})$ of the patient was $79 \%$ of the expected value, whereas the lean body mass was $59 \%$ of the expected value.

\section{Discussion}

This study confirms previous observations of decreased amino acid concentrations in patients with the glucagonoma syndrome. ${ }^{17}$ It shows that this is probably caused by an increased clearance of amino acids. The most noticeable changes were seen in the gluconeo- and ureagenic amino acids: alanine, glycine, methoinine, proline, and serine. Since glucagon does not increase muscular uptake of amino acids $^{2}$ but increases urea synthesis, ${ }^{23}$ the increased clearance is probably the result of increased hepatic uptake and conversion, and this is also indicated by the increased rate of urea synthesis.

Infusion of amino acids raised the total amino acid concentration to $2.2 \mathrm{mmol} / 1$, which is less than $50 \%$ of the value reached in normal people. Despite this, the rate of urea synthesis was increased in the patient. This is in accordance with studies in rats, where chronic hyperglucagonaemia reduced the amino acid concentration but increased the rate of urea synthesis, resulting in loss of nitrogen from organ proteins. ${ }^{5}$

Both the total body weight and the lean body mass were reduced in the patient, but the latter was reduced to a much greater extent suggesting that most of the weight loss in patients with glucagonoma syndrome is accounted for by loss of organ proteins.

It is therefore possible that the weight loss of patients with glucagonoma syndrome is due to an increased hepatic clearance and conversion of amino- $\mathrm{N}$ to urea- $\mathrm{N}$ leading to reduced amino acid concentrations, and organ protein catabolism.

This observation supports the hypothesis that changes in hepatic conversion of amino acids may regulate actively the rate of catabolism in organs. ${ }^{18}$

Our thanks to Dr J J Holst, Department of Medical Physiology C, University of Copenhagen, for the initial diagnostic determination of glucagon concentration.

1 Mallinson CN, Bloom SR, Warin AP, Salmon PR, Cox B. A lucagonoma syndrome. Lancet 1974 ; ii: 1-5.

2 Wolfe BM, Culebras JM, Aoki TT, et al. The effect of glucagon on protein metabolism in normal man. Surgery 1979; 86: 248-57.

3 Boden G, Rezvani I, Owen OE. Effects of glucagon on plasm amino acids. $\mathcal{F}$ Clin Invest 1984; 73: 785-93.

4 Malette LE, Exton JH, Park CR. Effects of glucagon on amin acid transport and utilization in perfused rat liver. $\mathcal{F}$ Biol Chem 1969; 44: 5724-8.

5 Almdal TP, Vilstrup H. Loss of nitrogen from organs in rats induced by exogenous glucagon. Endocrinology 1988; 123: 2182-6.

Forbes GB, Bruining GJ. Urinary creatinine excretion and lean body mass. Am $\mathcal{F}$ Clin Nutr 1976; 29: 1359-66. 7 Heindorff $\mathrm{H}$, Vilstrup $\mathrm{H}$, Bucher D, Billesbølle P, Thygesen V. Increased hepatic amino nitrogen conversion afte elective cholecystectomy in man. Clin Sci 1988; 74: 539-45. acids: relation to liver function. Gut 1980; 21: 990-5. 
9 Hansen BA, Vilstrup H. Increased intestinal hydrolysis of urea in patients with alcoholic cirrhosis. Scand 7 Gastroenterol $1985 ; 20: 346-50$.

10 Shizgal HM. Body composition. In: Fishers P, ed. Surgical nutrition. Boston: Little, Brown \& Co, 1983: 3-17.

11 Lindberg W, Natvig H, Rygh A, Svendsen $K$. Weight and height in adult men and women. Tidskr Nor Laegeforen 1956, 361-8.

12 Goodwin JF. Spectophotometric quantitation of plasma and urinary amino nitrogen with fluorodinitrobenzene. Stand Meth Clin Chem 1970; 6: 89-98.

13 Fawcett JK, Scott JE. A rapid and precise method for the determination of urea. F Clin Pathol 1960; 13: 156-9.

14 Bergmeyer HU, Bernt E, Schmidt F, Stork H. In: Bergmeyer
HU, ed. Methoden der enzymatischen analyse. Weinheim:
Verlag Chemie, 1974: 1163-72.

15 Heding LG. Determination of total serum insulin (IRI) in insulin treated diabetic patients. Diabetologia 1971; 8: 260-9.

16 Heding L. Radioimmunological determination of pancreatic and gut glucagon in plasma. Diabetologia $1971 ; 7: 10-7$

17 Roth E, Mühlbacher F, Karner J, Hamilton G, Funovics J. Free amino acid levels in muscle and liver of a patient with Free amino acid levels in muscle and liver of a patient

18 Vilstrup H, Hansen BA, Almdal T, Petersen KF, Sigsgaard, Poulsen HE. The capacity of urea synthesis in rats: regulation and physiological importance. In: Soeters PB. Wilson tion and physiological importance. In: Soeters PB. Wilson JHP, Meijer AJ, Holm E, eds. Advances in ammonia metabolism and hepatic enceph
Excerpta Medica, 1988: 79-85. 